\title{
The reflection of the Syrian civil war on the emergency department and assessment of hospital costs
}

\author{
Ali Karakuş, M.D., ${ }^{1}$ Erhan Yengil, M.D., ${ }^{2}$ Seçkin Akkücük, M.D., ${ }^{3}$ \\ Cengiz Cevik, M.D., ${ }^{4}$ Cem Zeren, M.D., ${ }^{5}$ Vedat Uruc, M.D. ${ }^{6}$ \\ Departments of ${ }^{1}$ Emergency Medicine, ${ }^{2}$ Family Medicine, ${ }^{3}$ General Surgery, ${ }^{4}$ Otorhinolaryngology, \\ ${ }^{5}$ Forensic Medicine, ${ }^{6}$ Orthopedics, Mustafa Kemal University Faculty of Medicine, Hatay
}

\begin{abstract}
BACKGROUND: In the present study, it was aimed to assess the demographics, clinical features, and treatment costs of cases referred to our hospital after the Syrian civil war.

METHODS: Of I 355 Syrian civil war victims referred to our hospital during the I4-month period between June $201 \mathrm{I}$ and July 2012 , 482 cases presenting to the emergency department were included in the study. The electronic data of these patients were retrospectively analyzed.

RESULTS: Of 482 cases, 428 were male (88.8\%) and 54 (I I.2\%) were female, with a mean age of $30.4 \pm$ I 4.9 years (I-79 years). The mean age was $30.8 \pm 17.2$ years ( $1-79$ years) in males and $27.3 \pm 16.9$ years ( $1.5-66$ years) in females. There was a significant difference in terms of $\operatorname{sex}(p=0.007)$. It was found that the majority of the cases $(41.1 \%)$ were aged $21-30$ years. The highest number of admissions was recorded in June 201 I (I59 patients, 33\%), whereas the lowest number of admissions was in September 201 I (5 patients, I\%). All cases were transported to our hospital from nearby district hospitals and camps by emergency medical services. The most frequent presenting complaint was gunshot injury (338 cases, $70.1 \%$ ). The most common diagnosis was extremity injury (I53 cases, $31.7 \%)$. The number of forensic cases was found as 364 (75.5\%). Of all the cases, I 36 cases (28.2\%) were managed in the emergency service, and the remaining cases were admitted to other services. They were most frequently admitted to the orthopedics ward (I 46 cases, $30.3 \%$ ). The mean length of the hospital stay was 9.9 days (I-I4I). Overall, 456 cases (94.6\%) were discharged, 22 cases died, and 4 cases were transferred to other facilities. The mean cost per case was estimated as 3723 Turkish lira (TL) (I5-69556). A positive correlation was found between cost and length of hospital stay.
\end{abstract}

CONCLUSION: Among all Syrian cases, the majorities of young males and gunshot injuries was striking. Most of the cases were discharged after appropriate management. Preventive measures can avoid these negative outcomes and so avoidable costs will not occur, and this can preclude the damage to the budgets of the countries.

Key words: Avoidable costs, gunshot injury, Syrian case.

\section{INTRODUCTION}

Wars and conflicts are among the preventable causes of disease, which adversely affect human life and result in lifethreatening conditions or death in addition to disability. These combats have existed from the beginning of human history, and have continued throughout all eras in distinct locations of

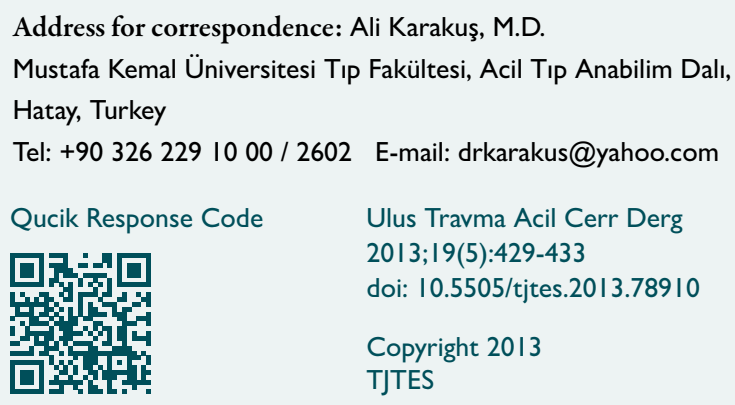

the world. It was reported that over 160 wars have occurred since the Second World War. ${ }^{[1]}$ Recent examples include the United States-Iraq and Israel-Palestine wars as well as wars and conflicts in countries such as Afghanistan, Libya and Egypt. As they threaten human health regarding disability, complications, and epidemic diseases, they pertain closely to the medical field. It was suggested that 190 million people have died due to wars and conflicts in the twentieth century, and that the majority are civilian deaths. ${ }^{[1,2]}$ In the present study, we aimed to contribute to the literature by observing the effect of a civil war on an emergency department and by identifying demographics, clinical features and avoidable costs.

\section{MATERIALS AND METHODS}

Of I 355 Syrian civil war victims who were referred to our hospital, a tertiary healthcare facility, during a 14-month period between June 20II and July 20I2, 482 cases presenting to the emergency department were included in the study. Patients 
presenting to clinics other than the emergency department were excluded. The electronic data of these patients were analyzed retrospectively. Patients were reviewed in terms of gender, age, time of presentation, place from which he/she was transferred, presenting complaint, diagnosis, forensic case status, ward of admission, length of stay, outcome, and cost.

\section{Statistical Analysis}

The Statistical Package for the Social Sciences (SPSS) for Windows 13.0 software was used in the statistical analysis. Continuous variables were evaluated using KolmogorovSmirnov test for normality. Associations between nominal variables were evaluated using the chi-square test, while differences in median values between groups were assessed by Kruskal-Wallis and Mann-Whitney $U$ tests. The linear regression model was applied to reveal factors effective on hospital costs. A value of $p<0.05$ was considered as significant in all statistical analyses.

\section{RESULTS}

Between June 20II and July 20I2, 28I,356 patients were admitted to our hospital, and $1355(0.48 \%)$ of them were Syrian; 27,398 patients were admitted to the emergency department, and 482 (I.75\%) of them were victims of the Syrian civil war. Four hundred twenty-eight of 482 cases were male (88.8\%) and 54 (1 I.2\%) were female, with a mean age of $30.4 \pm 14.9$ years ( $1-79$ years). The mean age was found as $30.8 \pm 17.2$ years ( $1-79$ years) in males and $27.3 \pm 16.9$ years (1.5-66 years) in females. A significant difference was found in terms of sex $(p=0.007)$. It was found that the majority of the cases ( 198 cases, $41.1 \%$ ) were aged $21-30$ years (Fig. I).

The highest number of admissions was recorded in June $201 \mathrm{I}$ (159 patients, 33\%) and the lowest in September 20II (5 patients, I\%).

All cases were transported to our hospital from nearby district hospitals and camps by emergency medical services. These patients were recorded in the Hatay Antakya Public Stateless and Exile Agency and Hatay Disaster Agency registry.

The most frequent presenting complaint was gunshot injury (338 cases, 70.1\%). Gunshot injuries included lead injury, injury related to the shell, mine explosion, and bullet wounds. The medical emergency group included chest pain, shortness of breath, intoxication, and snake bites. There were causes of abdominal pain and of headache in the surgical emergency group, while traffic accidents and falls were recorded in other forensic case groups. Green code diseases, which were directed to outpatient clinics other than the non-traumatic emergency department, were included into the other diagnosis group (Fig. 2).

When diagnosis and age groups were considered, it was found that extremity injury (I53 cases, 31.7\%) was most common.

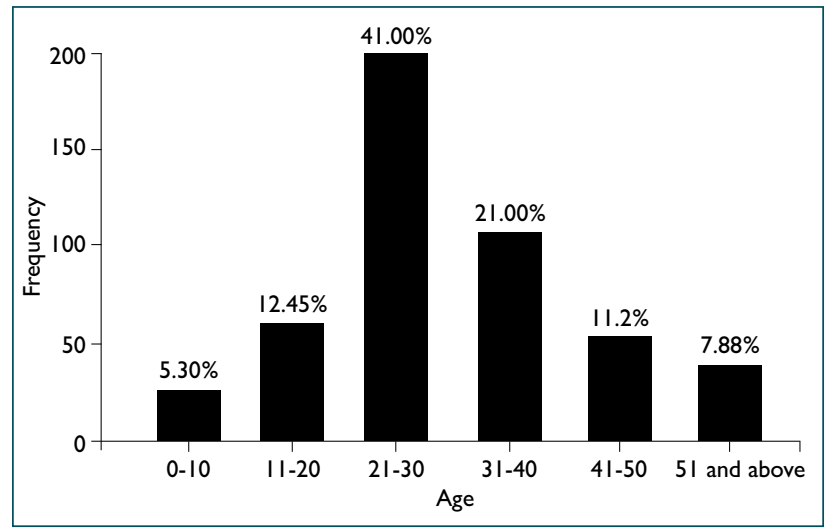

Figure 1. Age distribution of cases.

Of the 482 cases presenting to the emergency department, it was found that 364 cases $(75.5 \%)$ were in the forensic case group (Table I).

When management and outcomes were considered, it was found that the number of patients managed in the emergency department/total number of patients admitted to emergency department was $136 / 607$ patients (26.8\%). Of the 136 cases, 127 patients $(26.4 \%)$ were discharged on an outpatient basis, 6 patients (I.2\%) died in the emergency department, and 3 patients $(0.6 \%)$ were transferred from the emergency department. Of the 482 cases, 346 (7I.8\%) were admitted to hospital, of whom one was transferred to another facility and 16 died. Overall, 456 patients $(94.6 \%)$ were discharged, while 22 patients $(4.6 \%)$ died and $4(0.8 \%)$ were transferred.

When the ward of admission and outcomes were considered, it was seen that patients were most frequently admitted to the orthopedics ward (I46 cases, 30.3\%) (Table 2). The mean length of hospital stay was 9.9 days (I-|4| days). The mean

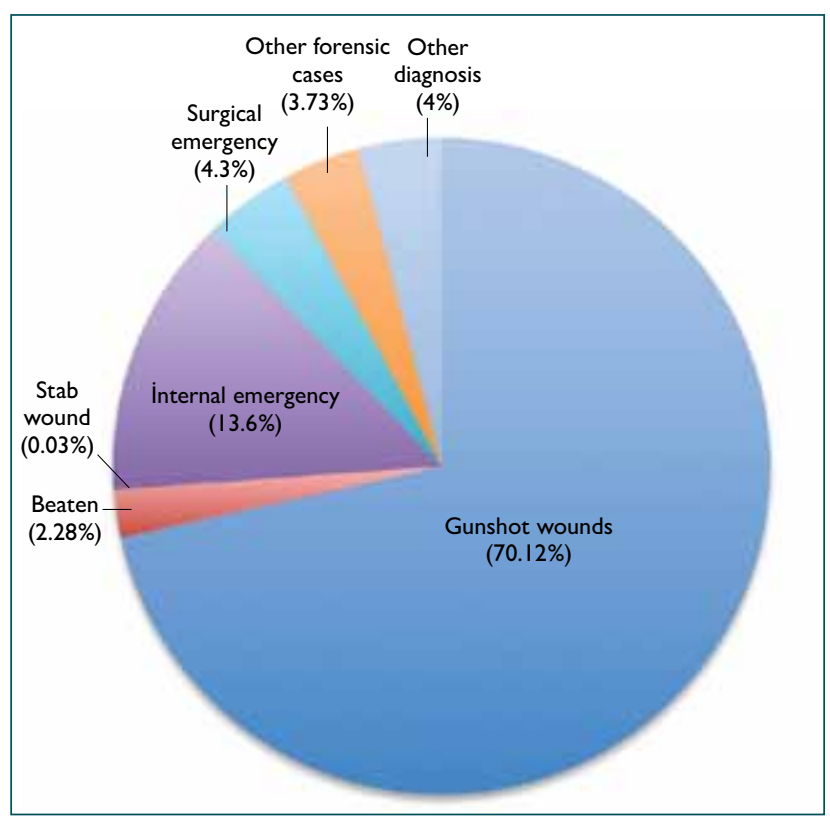

Figure 2. Distribution of presenting complaints according to cases. 
Table I. Age groups and diagnosis

\begin{tabular}{|c|c|c|c|c|c|c|c|}
\hline Age and diagnosis & $0-10$ & ||$-20$ & $21-30$ & $31-40$ & $41-50$ & $5 I$ and above & Total (n) \\
\hline Head injury & 1 & 4 & 20 & II & 3 & 1 & 40 \\
\hline Internal disease & 9 & 10 & 27 & II & II & 25 & 93 \\
\hline Maxillofacial trauma & 1 & 1 & 12 & II & 3 & 2 & 30 \\
\hline Spinal injury & 0 & 1 & 3 & 7 & 1 & 0 & 12 \\
\hline Cardiac injury & 0 & 1 & 1 & 2 & 2 & 0 & 6 \\
\hline Chest injury & 0 & 5 & 23 & 6 & 9 & 1 & 44 \\
\hline Abdominal injury & 0 & 4 & 16 & 10 & 9 & 2 & 41 \\
\hline Pelvic injury & 0 & 0 & 7 & 1 & 1 & 0 & 9 \\
\hline Extremity injury & 6 & 29 & 66 & 35 & 11 & 6 & 153 \\
\hline Ocular injury & 1 & 4 & 15 & 6 & 2 & 1 & 29 \\
\hline Surgical emergency & 8 & 1 & 8 & 6 & 2 & 0 & 25 \\
\hline Total (n) & 26 & 60 & 198 & 106 & 54 & 38 & 482 \\
\hline
\end{tabular}

Table 2. Admissions and outcomes

\begin{tabular}{|c|c|c|c|c|c|c|c|c|}
\hline \multirow{2}{*}{$\begin{array}{l}\text { Department of admission } \\
\text { and outcomes }\end{array}$} & \multicolumn{2}{|c|}{ Discharged } & \multicolumn{2}{|c|}{ Died } & \multicolumn{2}{|c|}{ Transferred } & \multicolumn{2}{|c|}{ Total } \\
\hline & $\mathbf{n}$ & $\%$ & $\mathbf{n}$ & $\%$ & $\mathbf{n}$ & $\%$ & $\mathbf{n}$ & $\%$ \\
\hline Orthopedics & 145 & 30.1 & 1 & 0.2 & 0 & 0 & 146 & 3.3 \\
\hline Emergency & 127 & 26.3 & 6 & 1.2 & 3 & 0.6 & 136 & 28.2 \\
\hline General Surgery & 42 & 8.7 & 9 & 1.9 & 0 & 0 & 51 & 10.6 \\
\hline Ophthalmology & 31 & 6.4 & 0 & 0 & I & 0.2 & 32 & 6.6 \\
\hline Cardiology & 24 & 5.0 & 2 & 0.4 & 0 & 0 & 26 & 5.4 \\
\hline Neurosurgery & 22 & 4.6 & 3 & 0.6 & 0 & 0 & 25 & 5.2 \\
\hline Otorhinolaryngology & 25 & 5.2 & 0 & 0 & 0 & 0 & 25 & 5.2 \\
\hline Plastic Surgery & 18 & 3.7 & 0 & 0 & 0 & 0 & 18 & 3.7 \\
\hline Thoracic Surgery & 11 & 2.3 & 0 & 0 & 0 & 0 & II & 2.3 \\
\hline Pediatrics & 4 & 0.8 & 0 & 0 & 0 & 0 & 4 & 0.8 \\
\hline Urology & 3 & 0.6 & 0 & 0 & 0 & 0 & 3 & 0.6 \\
\hline Pediatric Surgery & 2 & 0.4 & 0 & 0 & 0 & 0 & 2 & 0.4 \\
\hline Neurology & 1 & 0.2 & 1 & 0.2 & 0 & 0 & 2 & 0.4 \\
\hline Obstetrics \& Gynecology & I & 0.2 & 0 & 0 & 0 & 0 & I & 0.2 \\
\hline Total & 456 & 94.6 & 22 & 4.65 & 4 & 0.8 & 482 & 100 \\
\hline
\end{tabular}

length of hospital stay was 10.1 days (min: I - max: 141 ) in the 456 cases discharged, II.5 days (min: I - max: 30 ) in the patients transferred and 6.5 days (min: I - max: 20) in the exitus patients. No significant relationship was found between outcomes and length of hospital stay $(p=0.45)$.

When outcomes and age were considered, it was found that the mean age was lower in cases discharged compared to those who died ( $p=0.015)$ (Fig. 3).

When a correlation test was performed with continuous variables, a positive correlation was detected between cost and length of hospital stay $(p=0.000)(\mathrm{Fig} .4)$.
When diagnosis and costs were considered, it was found that the maximum cost occurred in patients who admitted to the hospital due to head-neck injury with an intracranial event (n: 40, 10287.90 Turkish lira (TL) [130 TL - 679/2 TL]). During this period, the number of patients in the emergency department was increased about $50 \%$ when compared to the prewar period. This overload caused staff insufficiency and new staff requirements. Further, new services and additional intensive care units were activated. All these caused additional costs and workloads.

\section{DISCUSSION}

Wars and conflicts negatively affect human life. The chaos 


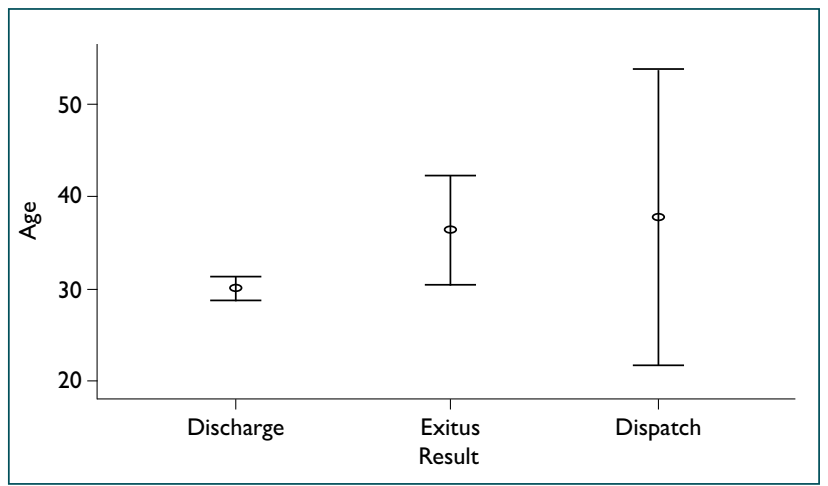

Figure 3. Assessment of age-outcome.

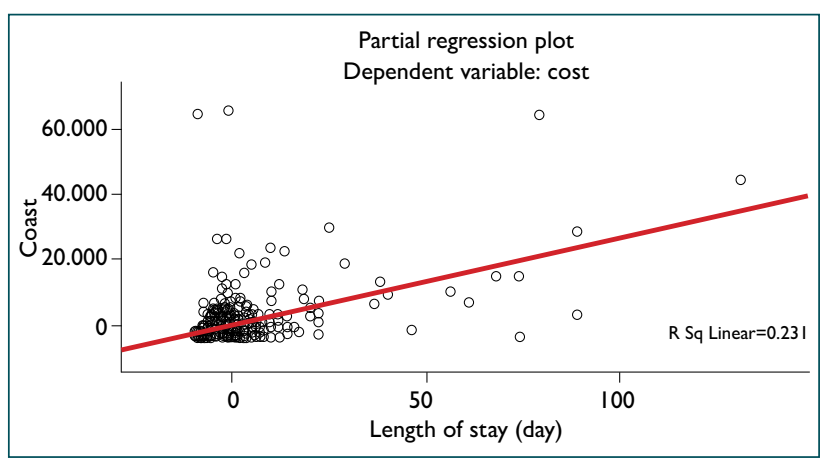

Figure 4. The relationship between cost and length of stay.

state in a country drives people to migrate to other countries, forcing them into refugee status. It particularly affects the young population and changes the structure of the general population. In the previous studies, it was suggested that the migrated population is mostly male $(70-100 \%)$ and in young age groups (16-34 years of age) $\cdot^{[3-5]}$ This inevitably affects the population in all respects. The finding that, of our 482 cases, 428 were male $(88.8 \%)$ with a mean age of $30.4 \pm 14.9$ years ( $I-79$ years) is consistent with the literature. This may indicate that the young, male population is responsible for working, maintaining life, and protecting the family and family circle.

All healthcare staff should be trained for natural disasters, accidents including multiple casualties, and conflicts and wars. It has been suggested that firearms have four mechanisms of action. ${ }^{[6]}$ In the first mechanism, there is an initial explosion, shock waves and visceral effects. ${ }^{[7,8]}$ The second mechanism is the shell effect of materials in the bomb. The third mechanism includes blunt trauma caused by force, and the fourth mechanism includes burns after flames. The first mechanism is considered as the most important mechanism causing disability and death. In the studies, it has been suggested that all casualties managed had gunshot injury. ${ }^{[4,5]}$ In our study, gunshot injury was the most common presenting complaint and mechanism of action. Among these, injuries caused by shell effect were the most frequent, followed by those caused by the effects of the initial explosion, blunt trauma and burns, and this may explain the lower mortality rates in our series. All bodily structures may be involved after injury and may threaten life. In a study by Mushtaque et al.,[5] it was found that extremities (47.9\%), abdomen (36.3\%) and lungs (31.3\%) were involved. In other studies, extremity injuries ranked first. ${ }^{[4,9-11]}$ In agreement with the literature, it was seen that extremities were the most commonly involved structures in our cases. This may suggest that structures with mobility are vulnerable in terms of injuries and may be more excessively involved.

Depending on their clinical status, patients may be discharged from the emergency department after management on an outpatient basis, while severe cases should be managed in wards and intensive care units. In one study, $59.5 \%$ of the patients were discharged from the emergency department after management on an outpatient basis, while 346 of 482 cases (71.8\%) were admitted to hospital in our series. ${ }^{[5]}$ Of the 136 patients managed in the emergency department on an outpatient basis in this series, 127 (26.4\%) were discharged. Patients may be discharged after management, or death may occur. Death usually occurs either as a result of the primary disease or potential secondary complications. In one study, it was found that $53.7 \%$ of the cases underwent surgery, and $3.03 \%$ of these cases died. ${ }^{[5]}$ In another study, it was found that the number of deaths caused by disease were more than deaths caused by injury during war (deaths caused by disease 24870 [3.5\%] vs. $130|2|$ [ $18.3 \%])^{[12]}$ In a case series including 31 cases, only 2 deaths occurred due to gunshot injury. [4] Of the 482 cases in our study, 456 cases $(94.6 \%)$ were discharged and 22 cases $(4.6 \%$ ) died (6 patients in the emergency department and 13 patients in wards because of clinical status and complications caused by gunshot injury and 3 due to cardiac failure, myocardial infarction and intracranial event in cardiology and neurology wards). The disposition of most patients in this series might be attributed to appropriate diagnosis and treatment on site.

In Article 14 of the Universal Declaration of Human Rights, it is proposed that "Everyone has the right to seek and to enjoy in other countries asylum from persecution". ${ }^{[3]}$ According to the registry of the United Nation's Refugee Agency, there were about 11,000 refugees in December 2008. ${ }^{[13]}$ This number was 25,459 in December 20II.[14] The Act of Insurance and General Health Insurance (\#55I0; 60/Ic) included stateless people and refugees in the scope of general health insurance. Because the conflict in Syria started in April 20II, 80,000 Syrian citizens had entered our country by August 2012, while 30,000 had returned to their country. Driven by AFAD (Agency of Disaster and Emergency Management), five tent camps were constructed in Hatay, two camps in Şanlıurfa and one camp in Gaziantep. There was also a shelter in Kilis including containers. Of the remaining 50,000 refugees, about 500 are still in hospitals. ${ }^{\left[{ }^{[5]}\right.}$ Over the previous one-year period, approximately 2100 casualties were transferred to 
hospitals from the Syrian border, and it was reported that expenses reached 150 million dollars as per April 2012. ${ }^{[16,17]}$ Patients transferred to our hospital were managed after being reported to the Hatay, Antakya Public Stateless and Exile Agency. In our cost analysis, it was found the mean cost per case was $3723 \mathrm{TL}$ (15-69556 TL). This might have been caused by poor prognosis and prolonged length of stay.

In conclusion, wars and conflicts as avoidable causes negatively affect human life. Among all Syrian cases, the majority of patients were young males, and gunshot injury was the striking cause of trauma. Most of the cases were discharged after appropriate management. Following precautionary measures, these negative outcomes and avoidable costs can be prevented, and strains on the budgets of the receiving countries may be precluded.

\section{Conflict of interest: None declared.}

\section{REFERENCES}

1. İz FB. Savaş ve çevre. Maltepe University School of Nursing Science and Art Journal 2009;2:113-7.

2. Pyakuryal P, Uprety K Economic \& legal impact of conflict on states \& people in south asia with specific reference to nepal. The Journal of Social, Political and Economic Studies 2005;30:234-40.

3. Buz S. The social profile of asylum seekers in Turkey. Turkish Journal of Police Studies 2008;10:1-14.

4. Zeren C, Arslan MM, Aydogan A, Ozkalipci O, Karakuş A. Firearm injuries documented among Syrian refugees in Antakya Turkey. British
Journal of Arts and Social Sciences 2012;5:1-5.

5. Mushtaque M, Mir MF, Bhat M, Parray FQ, Khanday SA, Dar RA, et al. Pellet gunfire injuries among agitated mobs in Kashmir. Ulus Travma Acil Cerrahi Derg 2012;18:255-9.

6. Cömert B. Conditions of War Intensive Care Unit. Intensive Care Medicine 2006;6:16-21.

7. Wightman JM, Gladish SL. Explosions and blast injuries. Ann Emerg Med 2001;37:664-78.

8. Mayorga MA. The pathology of primary blast overpressure injury. Toxicology 1997;121:17-28.

9. Gourgiotis S, Schmidt R. The experience of military surgeons from a north Afghanistan deployment and lessons for the future. Ulus Travma Acil Cerrahi Derg 2011;17:289-92.

10. Hebrang A, Henigsberg N, Golem AZ, Vidjak V, Brnić Z, Hrabac P. Care of military and civilian casualties during the war in Croatia. [Article in Croatian] Acta Med Croatica 2006;60:301-7. [Abstract]

11. Zouris JM, Walker GJ, Dye J, Galarneau M. Wounding patterns for U.S. Marines and sailors during Operation Iraqi Freedom, major combat phase. Mil Med 2006;171:246-52.

12. Uçar M, Deniz S. Turkish History Military Health Services. TAF Preventive Medicine Bulletin 2012;11:103-18.

13. Karadağ O,Altıntaş KH. Mülteciler ve sağlık. TAF Preventive Medicine Bulletin 2010;9:55-62.

14. http//www.amnesty.org.tr/ai/node/1872. 27 Feb 2012 - in the field of social security arrangements and access to health care of refugees and asylum-seekers. (Accessed: 08/10/2012).

15. http//www. last minute. com. (Accessed: 08/10/2012).

16. http//www. news. com. (Accessed: 08/10/2012).

17. http//www. news 10. com. (Accessed: 08/10/2012).

\section{KLINIKK ÇALIŞMA - ÖZET}

\section{Suriye'deki çatışmaların acil servise yansıyan yönü ve} hastane maliyetlerinin değerlendirilmesi

\section{Dr. Ali Karakuş, ${ }^{1}$ Dr. Erhan Yengil, ${ }^{2}$ Dr. Seçkin Akkücük, ${ }^{3}$ Dr. Cengiz Cevik, ${ }^{4}$ Dr. Cem Zeren, ${ }^{5}$ Dr. Vedat Uruc ${ }^{6}$}

Mustafa Kemal Üniversitesi, Tıp Fakültesi, ${ }^{1}$ Acil Tıp Anabilim Dalı, ${ }^{2}$ Aile Hekimliği Anabilim Dalı, ${ }^{3}$ Genel Cerrahi Anabilim Dalı, ${ }^{4}$ Kulak Burun Boğaz Anabilim Dalı, ${ }^{5}$ Adli Tıp Anabilim Dalı, ${ }^{6}$ Ortopedi ve Travmatoloji Anabilim Dalı, Hatay

AMAÇ: Bu çalışmada, Suriye'de yaşanan çatışmalar sonrası hastanemize getirilen olguların demografisi, klinik özellikleri ve yapılan harcamaların değerlendirilmesi amaçlandı.

GEREÇ VE YÖNTEM: Bu amaçla Haziran 20I I-Temmuz 2012 yılları arasındaki I 4 aylık dönemde hastanemize getirilen I355 Suriyeli olgunun acil servis girişi olan 482'si çalışmaya alındı. Hastaların bilgisayar verileri geriye dönük olarak incelendi.

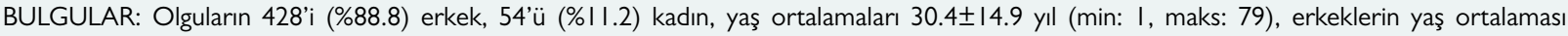
$30.8 \pm 17.2 \mathrm{yıl} \mathrm{(min:} \mathrm{I,} \mathrm{maks:} \mathrm{79),} \mathrm{kadınların} \mathrm{yaş} \mathrm{ortalaması} \mathrm{ise} 27.3 \pm 16.9$ yıl (min: I.5, maks: 66) olarak belirlendi, cinsiyet bakımından aralarında istatistiksel olarak anlamlı bir fark saptandı $(p=0.007)$. Olguların en çok 21 -30 yaş grubunda (\%4I.I) olduğu belirlendi. En fazla başvurunun I59 (\%33) kişiyle Haziran 20 I I, en az ise beş kişi (\% I) ile Eylül 20 I I'de olduğu tespit edildi. Hastalar I I 2 Acil Servis ambulansları ile çevre ilçe hastaneleri ve kamplardan getirildi. Acil servise başvuru sebebi en sık 338 olgu (\%70.I) ile ateşli silah yaralanması idi. En sık konulan tanı ise ekstremite yaralanmasıydı (I53 olgu, \%3।.7). Adli olgu sayısı 364 (\%75.5) tespit edildi. Yüz otuz altı (\%28.2) hastanın acil servisde takip ve tedavisi yapıldı. Hastalar en sık ortopedi ve travmatoloji bölümüne yatırılarak tedavi edildi (I 46 olgu, \%30.3). Ortalama yatış süresi 9.9 gün (I-I4I gün) idi. 456 olgu (\%94.6) taburcu edilirken, 22 olgu (\%4.6) öldü, dört olgu (\%0.8) ise sevk edildi. Olguların maliyeti ortalama 3723 TL (min: 5 TL, maks: 69556 TL) olarak bulundu. Sürekli değişkenler arası korelasyon testi yapıldığında maliyeti ve yatış süresi arasında pozitif korelasyon saptandı $(p=0.000)$.

TARTIŞMA: Getirilen olgular içinde genç erkek ve ateşli silah yaralanması olgularının çokluğu dikkat çekti. Olguların çoğunluğu uygun takip ve tedavi sonrasında taburcu edildi. Alınacak tedbirler sonrasında bu kötü sonuçlar engellenebilecek, önlenebilir maliyetler ortaya çıkmayacak ve ülke bütçelerinin zarar görmesi önlenebilecektir.

Anahtar sözcükler: Önlenebilir maliyet, ateşli silah yaralanması, Suriyeli olgu.

Ulus Travma Acil Cerr Derg 2013;19(5):429-433 doi: 10.5505/tjtes.2013.78910 